GRASAS Y ACEITES 66 (1)

January-March 2015, e066

ISSN-L: 0017-3495

doi: http://dx.doi.org/10.3989/gya.0829142

\title{
The importance of pretreatment tailoring on the performance of ultrafiltration membranes to treat two-phase olive mill wastewater
}

\author{
J.M. Ochando Pulido ${ }^{\bowtie}$ \\ Chemical Engineering Department, University of Granada, 18071 Granada, Spain \\ ${ }^{\square}$ Corresponding author: jmochandop@ugr.es
}

Submitted: 20 August 2014; Accepted: 23 October 2014

SUMMARY: In this work, the performance of an ultrafiltration (UF) membrane in the treatment of the effluents by-produced by olive mills is addressed by applying different pretreatments on the raw effluents. By conducting a photo-catalytic process $\left(\mathrm{UV} / \mathrm{TiO}_{2} \mathrm{PC}\right)$ after $\mathrm{pH}$-temperature flocculation $(\mathrm{pH}-\mathrm{T} \mathrm{F})$ higher threshold flux values were observed for all feed stocks than by applying solely the $\mathrm{pH}-\mathrm{T}$ F process, with an $18.8-34.2 \%$ increment. In addition, the performance of the UF membrane was also improved in terms of rejection efficiency, such that higher rejection values were yielded by the membrane for the organic pollutants $\left(\mathrm{R}_{\mathrm{COD}}\right)$ by 48.5 vs. $39.9 \%$ and 53.4 vs. $42.0 \%$. The UF membrane performance was also improved in terms of the volume feed recovery factor (VFR), achieving up to 88.2 vs. $87.2 \%$ and 90.7 vs. $89.3 \%$. Results in the same line were also observed when the highly polluted olives oil washing wastewater raw stream was previously mixed with the effluent stream coming from the washing of the olives. This permits the UF to permeate, achieving the standard limits to reuse the purified effluent for irrigation purposes (COD values below $1000 \mathrm{mg} \cdot \mathrm{L}^{-1}$ ), which makes the treatment process cost-effective and results in making the olive oil production process environmentally friendly.

KEYWORDS: Olive mill wastewater; Pretreatment tailoring; Threshold flux; Ultrafiltration; Wastewater treatment

RESUMEN: La importancia del pretratamiento focalizado para el rendimiento de las membranas de ultrafiltración en el tratamiento de las aguas residuales de la industria oleícola. En este estudio se aborda el rendimiento de una membrana de ultrafiltración (UF) para el tratamiento de los efluentes generados por la industria oleícola, mediante la aplicación de distintos pretratamientos. Tras aplicar un proceso fotocatalítico $\left(\mathrm{UV} / \mathrm{TiO}_{2} \mathrm{PC}\right)$ después de una floculación pH-temperatura ( $\mathrm{pH}-\mathrm{T} \mathrm{F}$ ) se observaron flujos límite para todos los efluentes mayores que tras la aplicación únicamente del proceso pH-T F, con incrementos del 18.8-34.2\%. Además, el rendimiento de la membrana de UF mejoró en términos de eficiencia de rechazo, con mayores valores de rechazo respecto de los contaminantes orgánicos $\left(\mathrm{R}_{\mathrm{COD}}\right), 48.5$ vs. $39.9 \%$ y 53.4 vs. $42.0 \%$. El rendimiento de la membrana mejoró también en términos de recuperación de volumen de alimentación (VRF), alcanzando hasta un 88.2 vs. 87.2\% y 90.7 vs. $89.3 \%$. Se observaron resultados en la misma línea cuando las aguas residuales del lavado del aceite, altamente contaminadas, fueron previamente mezcladas con el efluente generado en el lavado de las aceitunas. Esto permite que el permeado de la UF cumpla con los límites estándar para la utilización del efluente para riego (valores de la DQO inferiores a $1000 \mathrm{mg} \mathrm{L}^{-1}$ ), favoreciendo la eficiencia económica del proceso de tratamiento y permitiendo que el proceso de producción del aceite de oliva pueda ser respetuoso con el medio ambiente.

PALABRAS CLAVE: Agua residual de la industria oleícola; Flujo límite; Pretratamiento focalizado; Tratamiento de aguas residuales; Ultrafiltración

Citation/Cómo citar este artículo: Ochando Pulido JM. 2015. The importance of pretreatment tailoring on the performance of ultrafiltration membranes to treat two-phase olive mill wastewater. Grasas Aceites $\mathbf{6 6}$ (1): e066. doi: http://dx.doi. org/10.3989/gya.0829142.

Copyright: (c) 2015 CSIC. This is an open-access article distributed under the terms of the Creative Commons Attribution-Non Commercial (by-nc) Spain 3.0 Licence. 


\section{INTRODUCTION}

The seasonal production of olive oil using continuous centrifugation-based technology has replaced the ancient batch press method to cope with the increasing worldwide demand for olive oil in the last decades. As a side-effect, this growing demand has led to a substantial increase in the effluents generated by olive oil industries, commonly called olive mill wastewater (OMW).

The two-phase continuous centrifugation system appears to be more ecological than the three-phase technology and thus has been strongly promoted in Spain. Two main effluents are generated in twophase olive oil mills, which result from the washing procedure of the olives (olives washing wastewater, OWW) and from the washing of the olive oil during vertical centrifugation (olive oil washing wastewater, OOW).

Currently, an average-sized modern olive oil factory leads to a daily amount of $10-15 \mathrm{~m}^{3}$ of OOW, which amounts to $1 \mathrm{~m}^{3}$ of OWW per ton of processed olives. In Spain alone, the main olive oil producer worldwide, this signifies a total amount of more than 9 million $\mathrm{m}^{3}$ of OMW per year, which represents a huge volume of these highly contaminant effluents. What is more, olive oil production is now an emergent agro-food industry in China and several other countries such as the USA, Australia and the Middle East, hence the treatment of OMW is becoming a task of global concern.

Direct disposal of these effluents to surface waters, although still practiced, is both hazardous and illegal, resulting in severe pollution consequences (Voreadou, 1989). OMW cannot be directly disposed for irrigation purposes either. Uncontrolled discharge of these effluents generates odor nuisance, soil contamination, plant growth inhibition, underground leaks, water body pollution and hindrance of self-purification processes, as well as negative impacts on the aquatic fauna and the ecological status (Asfi et al., 2012; Borja et al., 2006; Danellakis et al., 2011; Karaouzas et al., 2011; Ntougias et al., 2013).

In 1981 the Spanish Government, as in other Mediterranean countries, prohibited the direct discharge of these effluents into rivers since high pollution levels were detected in the Guadalquivir river basin, and subsidized the construction of artificial ponds for the separate storage and natural evaporation of OWW and OOW (Annesini and Gironi, 1991). Over the years, this rule resulted inefficient as a consequence of the low evaporation potential of these ponds, the hazardous underground leaks derived from frequent deficiencies in their construction and odor release to the surroundings.

The highest organic pollutant concentration remains in the OWW effluent, including phenolic compounds, organic acids, tannins and organohalogenated contaminants, which are phytotoxic and refractory, thus resistant to biological degradation. Hence, biological treatment of OMW is currently not applied at industrial scale (Ammary, 2005; Ena et al., 2007; Fountoulakis et al., 2002; Garrido et al., 2002; Hodaifa et al., 2008; Marques, 2001).

As a consequence, a plethora of other reclamation treatments as well as combined processes have been proposed but have not led to completely satisfactory results, such as thermal concentration (Annesini and Gironi, 1991; Paraskeva and Diamadopoulos, 2006), treatments with lime and clay (Aktas et al., 2001; Al-Malah et al., 2000), composting (Bouranis et al., 1995; Cegarra et al., 1996; Papadimitriou et al., 1997), biosorption (Martínez-Nieto et al., 2010; Hodaifa et al., 2013), coagulation-flocculation (Martínez-Nieto et al., 2011a; Sarika et al., 2005; Stoller, 2009), advanced oxidation (Beltrán et al., 2000; Martínez-Nieto et al., 2011b; Sacco et al., 2012), electrocoagulation (Inan et al., 2004; Tezcan et al., 2006) and hybrid processes (Grafias et al., 2010; Lafi et al., 2009; Rizzo et al., 2008).

Within this context, pressure-driven membrane technology can be a potential solution for the reclamation of these highly contaminated effluents. However, the control of fouling is a key parameter to increase the profitability of membrane processes during operation and to avoid excessive overdesign of the membrane plant (Ochando Pulido et al., 2012 a,b; Stoller, 2009, 2011).

In this respect, an optimized control of the membrane operation requires adequate pretreatment tailoring, which means a proper design of the pretreatment processes in order to avoid high fouling rates on the membranes, which would rapidly lead to zero flux conditions if no pretreatment is conducted on the raw effluent upstream of the UF operation (Ochando Pulido et al., 2012 a,b, 2013 a,b; Stoller, 2009, 2011). Specifically, it is important to shift the mean particle size distribution of the foulants $\left(d_{p}\right)$ present in the feed stream to the membrane module away from the average pore diameter of the selected membrane $\left(D_{p}\right)$ to avoid constriction, blocking and plugging of the pores, which often cause irreversible fouling.

In this work, the treatment of the main effluents generated by olive mills operating with the two-phase production technology by ultrafiltration (UF) is addressed. The importance of pretreatment tailoring in the performance of the UF membrane pilot plant is studied by conducting different pretreatments on the raw effluents and comparing the results in terms of produced permeate flux and rejection efficiency. The aim was to enhance the steady-state performance of the UF plant and thus minimize fouling for a cost-effective scale-up of the process. 


\section{MATERIALS AND METHODS}

\subsection{UF membrane pilot plant}

The membranes pilot plant used for the experiments is schematically shown in Figure 1 . The operating pressure and the crossflow velocity over the membrane were measured and displayed by analogue manometers and a turbine flow meter and set by regulation valves $V_{1}$ and $V_{2}$, respectively. The feed flow rate was controlled at turbulent tangential velocity over the membrane $\left(550 \mathrm{~L} \cdot \mathrm{h}^{-1}\right.$, to promote $\mathrm{N}_{\mathrm{Re}}>4000$ ), to minimize concentration polarization in the boundary region of the membrane layer. The temperature was fixed at ambient conditions $\left(20 \pm 0.5^{\circ} \mathrm{C}\right)$, measured by a Pt100 sensor, and two plate heat exchangers (E1 and E2) served to maintain the temperature of the streams stable. The permeate flux was measured during the operation time by a precision electronic mass balance (AX-120 Cobos, $0.1 \mathrm{mg}$ accuracy). The UF module was supplied by GE Water and Process Technologies (model GM2540F), and present the characteristics reported in Table 1.

\subsection{Feed stocks: olive mill wastewater}

Samples of OWW and OOW were taken from olive oil mills located in Jaén and Granada (Spain) operating with the two-phase olive oil extraction process. OWW is a moderately polluted effluent, presenting high amounts of suspended solids but a low concentration of dissolved organic matter.

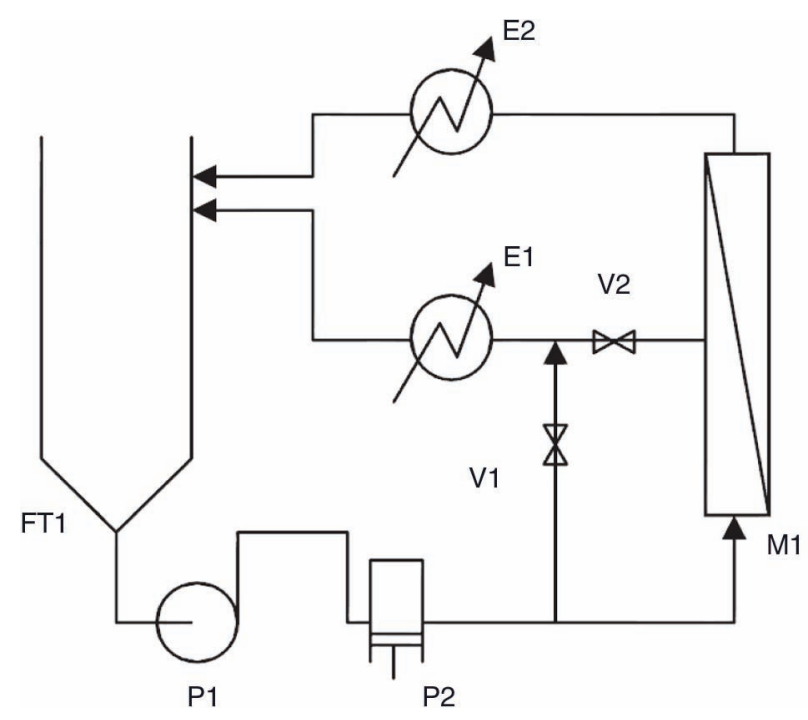

FIGURE 1. Flow diagram of the UF membrane pilot plant, $\mathrm{FT}_{1}$ : feedstock tank (100 L), $\mathrm{P}_{1}$ : booster pump, $\mathrm{P}_{2}$ : volumetric pump,

$\mathrm{V}_{1}$ : bypass regulation valve (precision $0.5 \mathrm{bar}$ ), $\mathrm{V}_{2}$ : concentrate regulation valve (precision $10 \mathrm{~L} \cdot \mathrm{h}^{-1}$ ), $\mathrm{E}_{1}$ and $\mathrm{E}_{2}$ : plate heat exchangers, $M_{1}:$ membrane housing provided with spiral wound (SW) UF membrane.
TABLE 1. Nominal characteristics of the selected UF membrane

\begin{tabular}{ll}
\hline Parameters & \multicolumn{1}{c}{ Parametric value } \\
\hline Model & GM2540F \\
Supplier & GE Water \& Process Tech. \\
Surface $\left(\mathrm{m}^{2}\right)$ & 2.5 \\
Permeability $\left(\mathrm{L} \cdot \mathrm{h}^{-1} \cdot \mathrm{m}^{-2} \cdot \mathrm{bar}^{-1}\right)$ & $5.2 \pm 0.5$ \\
Configuration & Spiral-wound $(\mathrm{SW})$ \\
Chemical structure & Thin film composite (TFC) \\
Chemical composition & Polyamide/polysulfone \\
MWCO $(\mathrm{kDa})$ & 8 \\
Average pore size $(\mathrm{nm})$ & 2 \\
Maximum pressure $(\mathrm{bar})$ & 16 \\
Maximum temperatura $\left({ }^{\circ} \mathrm{C}\right)$ & 50 \\
pH range & $1-11$
\end{tabular}

${ }^{\mathrm{a}} \mathrm{MWCO}$ : molecular weight cut off.

TABLE 2. Physicochemical composition of raw OWW and OOW, and 1:1 (v/v) mixture (OOWW)

\begin{tabular}{lccc}
\hline Parameters & OWW & OOW & OOWW \\
\hline $\mathrm{pH}$ & $6.3-6.5$ & $4.7-4.9$ & $5.9-6.3$ \\
$\mathrm{EC}\left(\mathrm{mS} \cdot \mathrm{cm}^{-1}\right)$ & $1.4-1.7$ & $2.4-2.6$ & $1.4-1.6$ \\
$\mathrm{TSS}\left(\mathrm{g} \cdot \mathrm{L}^{-1}\right)$ & $14.1-16.7$ & $8.0-9.8$ & $6.1-6.9$ \\
$\mathrm{COD}\left(\mathrm{g} \cdot \mathrm{L}^{-1}\right)$ & $0.7-0.8$ & $7.2-7.4$ & $4.1-4.2$ \\
$\mathrm{TPh}\left(\mathrm{mg} \cdot \mathrm{L}^{-1}\right)$ & $1.5-3.3$ & $162.7-171.1$ & $82.1-87.2$
\end{tabular}

EC: electroconductivity; TSS: total suspended solids; COD: chemical oxygen demand; $\mathrm{TPh}$ : total phenolic compounds; OWW: olive washing wastewater; OOW: olive oil washing wastewater OOWW: $1 / 1 \mathrm{v} / \mathrm{v}$ mixture of OWW and OOW.

Concentration values depend principally on the water flowrate used in the olive washing machines during the cleaning procedure of the fruit, but normally stand below the limits for discharge on suitable superficial terrains (Guadalquivir Hydrographical Confederation, 2006: total suspended solids TSS $<500 \mathrm{mg} \cdot \mathrm{L}^{-1}$ and chemical oxygen demand $\mathrm{COD}<1000 \mathrm{mg} \cdot \mathrm{L}^{-1}$ ). On the other hand, a high organic pollutant load in the form of dissolved matter is confirmed in OOW, most of which is phytotoxic and recalcitrant to biological degradation, such as phenolic compounds (Table 2).

\subsection{Pretreatments of the feed stocks}

The highly polluted raw OOW was subjected to different pretreatment processes studied and thoroughly described in a previous work by Ochando Pulido et al. (2014):

i) In first place, gridding of the raw effluent was carried out in order to remove the coarse particles (cut-size $\sim 300 \mu \mathrm{m}$ ). 
ii) Subsequently, pH-T flocculation ( $\mathrm{pH}-\mathrm{T} \mathrm{F}$ ) was performed by adding $\mathrm{HNO}_{3}(70 \% \mathrm{w} / \mathrm{w})$ under continuous stirring (320 r.p.m.).

iii) The supernatant at the outlet of the $\mathrm{pH}-\mathrm{T} \mathrm{F}$ process was either directly conducted to the UF unit and thereby referred to as OOW-F, or further pretreated by a photo-catalysis under ultraviolet irradiation (UV) with lab-made ferromagnetic-core $\mathrm{TiO}_{2}$ nanoparticles $\left(\mathrm{UV} / \mathrm{TiO}_{2} \mathrm{PC}\right)$, thus named OOW-FPC.

iv) Otherwise, OOW was also mixed with OWW in a 1:1 (v/v) proportion, thereby called OOWW, and subjected to the same pretreatment steps, and therefore named OOWW-F and OOWWFPC.

Finally, the differently pretreated streams were conducted to the UF pilot plant.

\subsection{Performance of the UF membrane}

The criterion to ensure the optimum operating strategy in batch operation for an already installed plant is to obtain the target solvent recovery in the shortest time possible, ensuring as well a concentration of impurities in the final permeate below the established standard limits.

The only degrees of freedom for the operation of the membrane plant in this case is the flux of the permeate stream of the membrane unit. The strategic choice can therefore consist of operating whether upon a permeate flux which is smaller or larger than the threshold value. The threshold flux $\left(\mathrm{J}_{\text {th }}\right)$ establishes the frontier between the low fouling and high fouling operating framework of a membrane (Bacchin et al., 1996; Field and Pierce, 2011).

Long-term measurements, which require the plant and, as a consequence, the production, to be stopped are surely not compatible with usual industrial practices. Therefore, it is necessary for the membrane plant engineers to develop threshold flux based methods, such as the one followed in this study, that require a limited amount of measurements of the flux values to operate the plant properly for a long period of time (Espinasse et al., 2002). The method consists basically of cycling the applied pressure up and down, by a constant pressure variation equal to $\Delta \mathrm{P}_{\mathrm{TM}}$, and to check for the restoration of the membrane permeability when the same pressure level is again applied after one cycle. Finally, the estimated $J_{\text {th }}$ values were contrasted with the experimental $J_{\text {ss }}$ values during the batch UF operation.

At the end of each experiment the membrane was rinsed with tap water for $15 \mathrm{~min}$ and stored in fresh tap water if no longer necessary, then chemical cleaning of the circuit with a $1 \mathrm{~N} \mathrm{NaOH}$ solution was performed in a closed loop for $30 \mathrm{~min}$.

\subsection{Analytical procedures}

All the analytical methods were carried out in triplicate with analytical-grade reagents: 70\% (w/w) $\mathrm{HNO}_{3}, 98 \%$ (w/w) $\mathrm{NaOH}, 98 \%$ (w/w) $\mathrm{Na}_{2} \mathrm{SO}_{3}, 30 \%$ (w/w) $\mathrm{NH}_{4} \mathrm{OH}, 37 \%$ (w/w) $\mathrm{HCl}$ and $30 \%$ (w/w) $\mathrm{FeCl}_{3}$, supplied by Panreac. Chemical oxygen demand (COD), total phenols (TPh), total suspended solids (TSS), electroconductivity (EC), $\mathrm{pH}$ and particle size distribution (Plus90 nanosizer, Brookhaven) were measured following standard methods (Greenberg et al., 1992).

\section{RESULTS AND DISCUSION}

\subsection{Pretreated feedstocks}

The physicochemical compositions of the effluent streams exiting each pilot-scale pretreatment are reported in Table 3. A higher TSS reduction of $25.0 \%$ can be observed for the OOW feedstock further pretreated by $\mathrm{UV} / \mathrm{TiO}_{2} \mathrm{PC}$ after $\mathrm{pH}-\mathrm{T} \mathrm{F}$ (OOW-FPC) than for OOW-F, as well as a higher organic pollutant load abatement, resulting in an increase of $21.3 \%$ for COD abatement and 19.2\% for TPh removal. Similar results are confirmed for OOWW, with increases of $58.3 \%, 58.4 \%$ and $27.5 \%$ for TSS, COD and TPh removal efficiencies, respectively, after $\mathrm{UV} / \mathrm{TiO}_{2} \mathrm{PC}$ was preceded by $\mathrm{pH}-\mathrm{T} \mathrm{F}$.

Moreover, by mixing the OWW and OOW streams (OOWW), an increment in the removal efficiencies of all parameters was noted after both pretreatment processes. Very significant enhancement was confirmed, from $75 \%$ for TSS, $75.2 \%$ for COD and $52.1 \%$ for $\mathrm{TPh}$ for the OOWW stream pretreated by $\mathrm{pH}-\mathrm{T} \mathrm{F}$ alone, up to $75 \%$ for TSS, $86.5 \%$ for COD and $56.9 \%$ for TPh for OOWW further pretreated by $\mathrm{UV} / \mathrm{TiO}_{2} \mathrm{PC}$.

\subsection{Influence of the different pretreatments on the threshold UF performance}

A good design of the pretreatment processes beforehand, called pretreatment tailoring, may increase the flux performance of the selected membrane accordingly.

The performance of the UF membrane as a function of the diversely pretreated feedstreams is reported in Table 4 , where $\mathbf{J}_{\text {th }}$ values measured on the UF membrane by the pressure-cycling method for each differently pretreated feedstock are given and contrasted with the steady-state permeate flux values registered during the batch UF operation, as well as the volume feed recovery (VFR) and the rejection efficiencies $\left(\mathrm{R}_{\mathrm{i}}\right)$ measured for TSS, COD and TPh.

It can be verified that the experimental $\mathrm{J}_{\mathrm{ss}}$ values attained during the batch-run operation of the UF membrane are very close to those $J_{\text {th }}$ estimated by the pressure-cycling method. 
The importance of pretreatment tailoring on the performance of ultrafiltration membranes to treat two-phase olive mill wastewater $\bullet 5$

TABLE 3. Physicochemical composition of raw OOW and OOWW exiting each pretreatment

\begin{tabular}{lrrrc}
\hline Parameters & OOW-F & OOW-FPC & OOWW-F & OOWW-FPC \\
\hline $\mathrm{pH}$ & $2.5 \pm 0.1$ & $2.9 \pm 0.1$ & $2.5 \pm 0.1$ & $3.1 \pm 0.1$ \\
$\mathrm{EC}\left(\mathrm{mS} \cdot \mathrm{cm}^{-1}\right)$ & $1.7 \pm 0.1$ & $1.8 \pm 0.1$ & $1.5 \pm 0.1$ & $1.5 \pm 0.1$ \\
$\mathrm{TSS}\left(\mathrm{g} \cdot \mathrm{L}^{-1}\right)$ & $1.6 \pm 0.1$ & $1.2 \pm 0.1$ & $0.4 \pm 0.1$ & $0.3 \pm 0.1$ \\
$\mathrm{COD}\left(\mathrm{g} \cdot \mathrm{L}^{-1}\right)$ & $14.5 \pm 0.2$ & $11.1 \pm 0.2$ & $3.6 \pm 0.2$ & $1.5 \pm 0.1$ \\
$\mathrm{TPh}\left(\mathrm{mg} \cdot \mathrm{L}^{-1}\right)$ & $172 \pm 2.1$ & $139 \pm 1.5$ & $82.5 \pm 1.6$ & $59.8 \pm 2.0$ \\
\hline
\end{tabular}

EC: electroconductivity; TSS: total suspended solids; COD: chemical oxygen demand; TPh: total phenolic compounds; OOW-F: olive oil washing wastewater after $\mathrm{pH}-\mathrm{T}$ flocculation; OOWW: $1 / 1 \mathrm{v} / \mathrm{v}$ mixture of OWW and olive oil washing wastewater (OOW) after $\mathrm{pH}-\mathrm{T}$ flocculation; OOW-FPC: olive oil washing wastewater after $\mathrm{pH}-\mathrm{T}$ flocculation and ultraviolet $(\mathrm{UV}) / \mathrm{TiO}_{2}$ photo-catalysis; OOWW: $1 / 1 \mathrm{v} / \mathrm{v}$ mixture of OWW and olive oil washing wastewater (OOW) after $\mathrm{pH}-\mathrm{T}$ flocc. and $\mathrm{UV} / \mathrm{TiO}_{2}$ photocatalysis.

TABLE 4. Performance of the UF membrane as a function of the diverse pretreated feedstream

\begin{tabular}{|c|c|c|c|c|c|}
\hline Feedstream & $\mathbf{L} \cdot \mathbf{h}^{-1} \cdot \mathbf{m}^{\mathbf{2}} \cdot \operatorname{bar}^{-1}$ & $\mathbf{L} \cdot \mathbf{h}^{-1} \cdot \mathbf{J}_{\mathrm{SS}}{ }^{-2} \cdot \mathrm{bar}^{-1}$ & $\begin{array}{c}\mathbf{R}_{\mathrm{TSS}} \\
\%\end{array}$ & $\begin{array}{c}\mathbf{R}_{\text {COD }} \\
\%\end{array}$ & $\begin{array}{c}\text { VFR } \\
\%\end{array}$ \\
\hline OOW-F & 8.2 & 8.0 & 100 & 39.9 & 87.2 \\
\hline OOW-FPC & 10.1 & 9.9 & 100 & 48.5 & 88.2 \\
\hline OOWW-F & 11.2 & 11.1 & 100 & 42.0 & 89.3 \\
\hline OOWW-FPC & 15.0 & 14.8 & 100 & 53.4 & 90.7 \\
\hline
\end{tabular}

$\mathrm{J}_{\mathrm{th}}$ : threshold permeate flux; $\mathrm{R}_{\mathrm{Tss}}$ : total suspended solids rejection; $\mathrm{R}_{\mathrm{COD}}$ : chemical oxygen demand rejection; VFR: volume feed recovery; OOWW: $1 / 1 \mathrm{v} / \mathrm{v}$ mixture of OWW and olive oil washing wastewater (OOW) after $\mathrm{pH}-\mathrm{T}$ flocculation; OOW-FPC: olive oil washing wastewater after $\mathrm{pH}-\mathrm{T}$ flocculation and ultraviolet (UV)/TiO ${ }_{2}$ photo-catalysis; OOWW: $1 / 1 \mathrm{v} / \mathrm{v}$ mixture of $\mathrm{OWW}$ and olive oil washing wastewater (OOW) after pH-T flocc. and $\mathrm{UV} / \mathrm{TiO}_{2}$ photo-catalysis.

Moreover, higher threshold flux values were observed for the UF membrane for all feedstocks by applying the UV/TiO 2 PC process after $\mathrm{pH}-\mathrm{T} \mathrm{F}$ (18.8-34.2\% increment) than by solely applying the $\mathrm{pH}-\mathrm{T} \mathrm{F}$ process. This is supported mainly by the additional abatement of organic pollutants (COD and $\mathrm{TPh}$ ) achieved by this photo-catalytic pretreatment step. In addition, the performance of the UF membrane was also improved in terms of rejection efficiency, such that major rejection values were yielded by the membrane for the organic pollutants $\left(\mathrm{R}_{\mathrm{COD}}\right)$, at 48.5 vs. $39.9 \%$ and 53.4 vs. $42.0 \%$. The UF membrane performance was also improved in terms of the volume feed recovery factor (VFR), achieving up to 88.2 vs. $87.2 \%$ and 90.7 vs. $89.3 \%$.

Turano et al. (2002) reported the use of centrifugation as pretreatment prior to the UF of OMW from a three-phase mill. However, despite the relevant COD reduction, the organic matter concentration in the final permeate stream was still too high.

Akdemir and Ozer (2009) examined the suitability of $\mathrm{pH}$ adjustment $(\mathrm{pH}=2)$ and cartridge filtration $(20 \mu \mathrm{m})$ as pretreatments for pressuredriven crossflow UF of OMW from a three-phase mill, reaching COD removal efficiencies up to $63 \%$. However, cartridge filtration is not a suitable operation for being transferred to an industrial scale and the whole treatment did not meet the discharge standard compliance pursued.
Stoller and Bravi (2010) reported a pretreatment step of either coagulation-flocculation by using aluminum sulfate (AS) or aluminum hydroxide (AH), or biological aerobic digestion by means of fungi in a biological immobilized bed reactor. The AH-pretreated stream did not provide satisfactory permeate flow rates on the UF step due to the similar size of the formed aggregates with respect to the membrane mean pore size, which led to quick fouling on the membrane, which similarly occurred after biodigestion, presumably owing to the residual biomass that gave rise to particle sizes close to those of the pores of the membrane.

In addition, better performance of the UF membrane was noted for the treatment of the mixed feedstock (OOWW) in contrast with OOW. In this case, the threshold flux values were significantly increased, from 8.2 up to $11.2 \mathrm{~L} \cdot \mathrm{h}^{-1} \cdot \mathrm{m}^{-2} \cdot \mathrm{bar}^{-1}$ for OOW-F in contrast with OOWW-F $(26.8 \%$ increment), whereas from 10.1 up to $15.0 \mathrm{~L} \mathrm{~h}^{-1} \mathrm{~m}^{-2} \mathrm{bar}^{-1}$ for OOW-FPC in contrast with OOWW-FPC (32.7\% increment). These UF performance benefits were also supported by higher VRF, at $89.3 \mathrm{vs}$. $87.2 \%$ (OOW-F vs. OOWW-F) and 90.7 vs. $88.2 \%$ (OOW-FPC vs. OOWW-FPC). Moreover, considerable major organic pollutant rejection was achieved for the mixed feedstream, 42.0 vs. $39.9 \%$ (OOW-F vs. OOWW-F) and 53.4 vs. $48.5 \%$ (OOW-FPC vs. OOWW-FPC). 
The different flux behavior of the UF membrane as a function of the diversely pretreated feedstreams can be explained by the fact that the pretreated OOW effluents feeding the UF membrane (OOW-F and OOW-FPC) are much more polluted than the pretreated 1:1 v/v mixtures of OOW and OWW (OOWW-F and OOWW-FPC). The latter present lower organic pollutants (COD), in particular, lower concentrations of phenolic compounds, which have molecular weights in the range of $0.5-20 \mathrm{kDa}$ and thus fall within the same range of the membrane's $\operatorname{MWCO}(8 \mathrm{kDa})$.

This significant improvement permits the stream exiting the UF unit after $\mathrm{pH}-\mathrm{T} \mathrm{F}$ and the UV/TiO PC process to fulfill the standard limits for the reuse of the purified effluent for irrigation purposes (COD values below $1000 \mathrm{mg} \cdot \mathrm{L}^{-1}$ ), aiding in the the costeffectiveness of the treatment process and permitting the olive oil production process to be deemed as environmentally friendly.

\section{CONCLUSIONS}

The criterion to ensure the optimum operating strategy in batch operation for an already installed plant is to obtain the target solvent recovery in the shortest time, ensuring as well, a concentration of impurities in the final permeate stream below the established standard limits. In this line, a good design of the pretreatment process, called pretreatment tailoring, may increase the flux performance of the selected membrane accordingly.

This is confirmed in this work, where higher threshold flux values were observed for the UF membrane for all feedstocks by applying an $\mathrm{UV} / \mathrm{TiO}_{2} \mathrm{PC}$ process after $\mathrm{pH}-\mathrm{T} \mathrm{F}$. What is more, the performance of the UF membrane was also improved in terms of rejection efficiency, such that higher rejection values were yielded by the membrane for organic pollutants. The UF membrane performance was also improved in terms of the volume feed recovery factor. Results in the same line were observed when the highly polluted OOW raw stream was previously mixed with OWW.

This permits the stream exiting the UF unit after $\mathrm{pH}-\mathrm{T} \mathrm{F}$ and the $\mathrm{UV} / \mathrm{TiO}_{2} \mathrm{PC}$ process to fulfill the standard limits for the reuse of the purified effluent for irrigation purposes, aiding in the cost-effectiveness of the treatment process and permitting to the olive oil production process to be considered environmentally friendly.

\section{ACKNOWLEDGMENTS}

The membrane pilot plant was constructed in the framework of the European project PHOTOMEM (contract no.FP7-SME-2011, grant 262470) and revamped under the European project ETOILE (contract no. FP7-SME-2007-1, grant 222331). Funding by the EC is gratefully acknowledged. The Spanish Ministry of Science and Innovation is also gratefully acknowledged for having funded the projects CTQ2007-66178 and CTQ2010-21411, as well as the University of Granada.

\section{REFERENCES}

Akdemir EO, Ozer A. 2009. Investigation of two ultrafiltration membranes for treatment of olive oil mill wastewater. Desalination 249, 660-666. http://dx.doi.org/10.1016/j. desal.2008.06.035.

Aktas ES, Imre S, Esroy L. 2001. Characterization and lime treatment of olive mill wastewater. Water Res. 35, 23362340. http://dx.doi.org/10.1016/S0043-1354(00)00490-5.

Al-Malah K, Azzam MOJ, Abu-Lail NI. 2000. Olive mills effluent (OME) wastewater post-treatment using activated clay. Sep. Purif. Technol. 20, 225-234. http://dx.doi.org/10.1016/ S1383-5866(00)00114-3.

Ammary BY. 2005. Treatment of olive mill wastewater using an anaerobic sequencing batch reactor. Desalination 177, 157-165. http://dx.doi.org/10.1016/j.desal.2004.12.006.

Annesini M, Gironi F. 1991. Olive oil mill effluent: ageing effects on evaporation behavior. Water Research 25, 1157-1960. http://dx.doi.org/10.1016/0043-1354(91)90210-H.

Asfi M, Ouzounidou G, Panajiotidis S, Therios I, Moustakas M. 2012. Toxicity effects of olive-mill wastewater on growth, photosynthesis and pollen morphology of spinach plants. Ecotox. Environ. Safe. 80, 69-75. http://dx.doi. org/10.1016/i.ecoenv.2012.02.030

Bacchin P, Aimar P, Sanchez V. 1996. Influence of surface interaction on transfer during colloid ultrafiltration. J. Membr. Sci. $115,49-63$. http://dx.doi.org/10.1016/0376-7388(95)00279-0.

Beltrán J, Torregrosa J, García J, Domínguez JR. 2000. Ozone treatment of olive mill wastewater. Grasas y Aceites 51, 32-46.

Borja R, Raposo F, Rincón B. 2006. Treatment technologies of liquid and solid wastes from two-phase olive oil mills. Grasas Aceites 57, 32-46. http://dx.doi.org/10.3989/gya. 2006.v57.i1.20.

Bouranis DL, Vlyssides AG, Drossopoulos JB, Karvouni G. 1995. Some characteristics of a new organic soil conditioner from the co-composting of olive oil processing wastewater and solid residue. Commun. Soil Sci. Plant Anal. 26, 2461-2472. http://dx.doi.org/10.1080/00103629509369460.

Cegarra J, Paredes C, Roig A, Bernal MP, García D. 1996. Use of olive mill wastewater compost for crop production. Int Biodet. Biodegrad. 38, 193-203. http://dx.doi.org/10.1016/ S0964-8305(96)00051-0.

Danellakis D, Ntaikou I, Kornaros M, Dailianis S. 2011. Olive oil mill wastewater toxicity in the marine environment: Alterations of stress indices in tissues of mussel Mytilus galloprovincialis. Aquat. Toxicol. 101, 358-366. http://dx.doi. org/10.1016/j.aquatox.2010.11.015.

Ena A, Carlozzi P, Pushparaj B, Paperi R, Carnevale S, Sacchi A. 2007. Ability of the aquatic fern Azolla to remove chemical oxygen demand and polyphenols from olive mill wastewater. Grasas Aceites 58, 32-46. http://dx.doi.org/10.3989/gya.2007. v58.i1.6.

Espinasse B, Bacchin P, Aimar P. 2002. On an experimental method to measure critical flux in ultrafiltration, Desalination 146, 91-96. http://dx.doi.org/10.1016/S0011-9164(02)00495-2.

Field, RW, Pearce, GK. 2011. Critical, sustainable and threshold fluxes for membrane filtration with water industry applications. Adv. Colloid Interface Sci. 164, 38-44. http://dx.doi. org/10.1016/j.cis.2010.12.008.

Fountoulakis MS, Dokianakis SN, Kornaros ME, Aggelis GG, Lyberatos G. 2002. Removal of phenolics in olive mill wastewaters using the white-rot fungus Pleurotus ostreatus. Water Res. 36, 4735-4744. http://dx.doi.org/10.1016/ S0043-1354(02)00184-7.

Garrido Hoyos SE, Martínez Nieto L, Camacho Rubio F, Ramos Cormenzana A. 2002. Kinetics of aerobic treatment of olive-mill wastewater (OMW) with Aspergillus 
terreus. Process Biochem. 37, 1169-1176. http://dx.doi.org/ 10.1016/S0032-9592(01)00332-6.

Grafias P, Xekoukoulotakis NP, Mantzavinos D, Diamadopoulos E. 2010. Pilot treatment of olive pomace leachate by vertical-flow constructed wetland and electrochemical oxidation: an efficient hybrid process. Water Research 44, 2773-2780. http://dx.doi.org/10.1016/j.watres.2010.02.015.

Greenberg AE, Clesceri LS, Eaton AD. 1992. Standard Methods for the Examination of Water and Wastewater, APHA/ AWWA/WEF, 16th ed., Washington DC. Cabs.

Hodaifa G, Eugenia-Sánchez M, Sánchez S. 2008. Use of industrial wastewater from olive-oil extraction for biomass production of Scenedesmus obliquus. Bioresour. Technol. 99, 1111-1117. http://dx.doi.org/10.1016/j.biortech.2007. 02.020 .

Hodaifa G, Ochando Pulido JM, Ben-Driss-Alami S, RodriguezVives S, Martinez-Ferez A. 2013. Kinetic and thermodynamic parameters of iron adsorption onto olive stones. Ind. Crops Prod. 49, 526-534. http://dx.doi.org/10.1016/j. indcrop.2013.05.039.

Inan H, Dimoglo A, Şimşek H, Karpuzcu M. 2004. Olive oil mill wastewater treatment by means of electro-coagulation. Sep. Purif. Technol. 36, 23-31. http://dx.doi.org/10.1016/ S1383-5866(03)00148-5.

Karaouzas I, Skoulikidis NT, Giannakou U, Albanis TA. 2011. Spatial and temporal effects of olive mill wastewaters to stream macroinvertebrates and aquatic ecosystems status. Water Res. 45, 6334 6346. http://dx.doi.org/10.1016/j.watres. 2011.09.014.

Lafi WK, Shannak B, Al-Shannag M, Al-Anber Z, Al-Hasan M. 2009. Treatment of olive mill wastewater by combined advanced oxidation and biodegradation. Separ. Purif. Technol. 70, 141-146. http://dx.doi.org/10.1016/j.seppur. 2009.09.008.

Martínez Nieto L, Ben Driss Alami S, Hodaifa G, Faur C, Rodríguez Vives S, Giménez Casares JA, Ochando J. 2010. Adsorption of iron on crude olive stones. Ind. Crop. Prod. 32, 467-471. http://dx.doi.org/10.1016/j.indcrop. 2010.06.017.

Martínez Nieto L, Hodaifa G, Rodríguez Vives S, Giménez Casares JA, Ochando J. 2011a. Flocculation-sedimentation combined with chemical oxidation process. Clean - Soil, air, water 39, 949-955. http://dx.doi.org/10.1002/clen. 201000594

Martínez Nieto L, Hodaifa G, Rodríguez Vives S, Giménez Casares JA, Ochando J. 2011b. Degradation of organic matter in olive oil mill wastewater through homogeneous Fenton-like reaction. Chem. Eng. J. 173, 503-510. http:// dx.doi.org/10.1016/j.cej.2011.08.022.

Marques IP. 2001. Anaerobic digestion treatment of olive mill wastewater for effluent re-use in irrigation. Desalination 137, 233-239. http://dx.doi.org/10.1016/S0011-9164(01) $00224-7$

Ntougias S, Gaitis F, Katsaris P, Skoulika S, Iliopoulos N, Zervakis GI. 2013. The effects of olives harvest period and production year on olive mill wastewater propertiesEvaluation of Pleurotus strains as bioindicators of the effluent's toxicity. Chemosphere 92, 399-405. http://dx.doi. org/10.1016/j.chemosphere.2013.01.033.

Ochando Pulido JM, Rodriguez-Vives S, Martinez-Ferez A. 2012a. The effect of permeate recirculation on the depuration of pretreated olive mill wastewater through reverse osmosis membranes. Desalination 286, 145-154. http:// dx.doi.org/10.1016/j.desal.2011.10.041

Ochando Pulido JM, Hodaifa G, Rodriguez-Vives S, MartinezFerez A. 2012b. Impacts of operating conditions on reverse osmosis performance of pretreated olive mill wastewater.
Water Res. 46, 4621-4632. http://dx.doi.org/10.1016/j. watres.2012.06.026.

Ochando Pulido JM, Hodaifa G, Victor-Ortega MD, RodriguezVives S, Martinez-Ferez A, 2013a. Reuse of olive mill effluents from two-phase extraction process by integrated advanced oxidation and reverse osmosis treatment, $J$. Hazard. Mater. 263, 158-67. http://dx.doi.org/10.1016/j. jhazmat.2013.07.015.

Ochando Pulido JM, Hodaifa G, Victor-Ortega MD, RodriguezVives S, Martinez-Ferez A, 2013b. Effective treatment of olive mill effluents from two-phase and three-phase extraction processes by batch membranes in series operation upon threshold conditions. J. Hazard. Mater. 263 , 168-176. http://dx.doi.org/10.1016/j.jhazmat.2013.03.041.

Ochando Pulido JM, Hodaifa G, Victor-Ortega MD, MartinezFerez A, 2014. A novel photocatalyst with ferromagnetic core used for the treatment of olive oil mill effluents from two-phase production process. The Scientific World Journal, 2014.

Papadimitriou EK, Chatjipavlidis I, Balis C. 1997. Application of composting to olive mill wastewater treatment. Environ. Technol. 18, 101-107.

Paraskeva P, Diamadopoulos E. 2006. Technologies for olive mill wastewater (OMW) treatment: A review. J. Chem. Technol. Biotechnol. 81, 475-485. http://dx.doi.org/10.1002/ jetb. 1553.

Rizzo L, Lofrano G, Grassi M, Belgiorno V. 2008. Pretreatment of olive mill wastewater by chitosan coagulation and advanced oxidation processes. Separ. Purif. Technol. 63, 648-653. http://dx.doi.org/10.1016/j.seppur.2008.07.003.

Sacco O, Stoller M, Vaiano V, Ciambelli P, Chianese A, Sannino D. 2012. Photocatalytic degradation of organic dyes under visible light on n-doped photocatalysts. Int. J. Photoenergy, 2012. DOI: $10.1155 / 2012 / 626759$.

Sarika R, Kalogerakis N, Mantzavinos D. 2005. Treatment of olive mill effluents. Part II. Complete removal of solids by direct flocculation with poly-electrolytes. Environ. Int. 31, 297-304. http://dx.doi.org/10.1016/j.envint.2004.10.006.

Stoller M. 2008. Technical optimization of a dual ultrafiltration and nanofiltration pilot plant in batch operation by means of the critical flux theory: a case study. Chem. Eng. Process. 47, 1165-1170. http://dx.doi.org/10.1016/j. cep.2007.07.012.

Stoller M. 2009. On the effect of flocculation as pretreatment process and particle size distribution for membrane fouling reduction. Desalination 240, 209-217. http://dx.doi. org/10.1016/j.desal.2007.12.042.

Stoller M. 2011. Effective fouling inhibition by critical flux based optimization methods on a NF membrane module for olive mill wastewater treatment. Chem. Eng. J. 168, 1140-1148. http://dx.doi.org/10.1016/j.cej.2011.01.098.

Stoller M, Bravi M. 2010. Critical flux analyses on differently pretreated olive vegetation wastewater streams: some case studies. Desalination 250, 578-582. http://dx.doi.org/10.1016/j. desal.2009.09.027.

Stoller M, Ochando Pulido JM. 2012. Going from a critical flux concept to a threshold flux concept on membrane processes treating olive mill wastewater streams. Procedia Eng. 44, 607-608. http://dx.doi.org/10.1016/j.proeng.2012.08.500.

Tezcan Ü, Uğur S, Koparal AS, Öğütveren ÜB. 2006. Electrocoagulation of olive mill wastewaters. Sep. Purif. Technol. 52, 136-141. http://dx.doi.org/10.1016/j.seppur. 2006.03.029.

Turano E, Curcio S, De Paola M G, Calabrò V, Iorio G. 2002. An integrated centrifugation-ultrafiltration system in the treatment of olive mill wastewater, J. Membr. Sci. 206, 519531. http://dx.doi.org/10.1016/S0376-7388(02)00369-1. 